\title{
Risk analysis of airplane accidents due to bird strikes using Monte Carlo simulations
}

\author{
H. Gotoh, M. Takezawa \& Y. Maeno \\ Nihon University, Tokyo, Japan
}

\begin{abstract}
Airplane accidents are generally more serious than accidents involving other methods of transportation. One cause of airplane accidents is a collision with a bird, which is called a bird strike. Particularly, if the bird is ingested by the jet engine, the airplane may lose power and crash. Therefore, it is useful to understand the bird strike risk before opening a new airport.

In this paper, the bird strike situation at existing airports in Japan is investigated, and the frequency and factors of bird strikes are presented (including geographic information, the number of takeoffs and landings, land use around the airport, and so on). Also, the relationships between these various factors and bird strike occurrence are analyzed. Furthermore, risk analysis is performed using Monte Carlo simulations of Haneda Airport as an example (which is the biggest airport in Japan), and bird strike countermeasures are suggested.
\end{abstract}

Keywords: bird strike, airport, airplane, risk analysis, Monte Carlo simulation.

\section{Introduction}

Upon takeoff or landing, an airplane can potentially collide with a bird, which is known as a bird strike. If a large bird were to be ingested by a jet engine, a serious accident may occur. According to a report by the Federal Aviation Administration (FAA), about 108,000 bird strikes occurred in the USA from 1990-2009 [1].

Based on bird strike data in Japan, the number of bird strikes that have occurred varies by region. If bird strike precautions are considered during the construction of a new airport, the risk can be significantly reduced. 
For this study, a questionnaire was distributed to airport officials regarding bird strike events at their respective airports. Also, all airports in Japan were investigated in terms of location and usage (such as the number of takeoffs and landings). Based on the results of the investigations, bird strike factors were analyzed and precautions were proposed for the development of new airports. Furthermore, as an example, the bird strike risk at Tokyo's Haneda Airport was analyzed using Monte Carlo simulation and bird strike countermeasures were suggested.

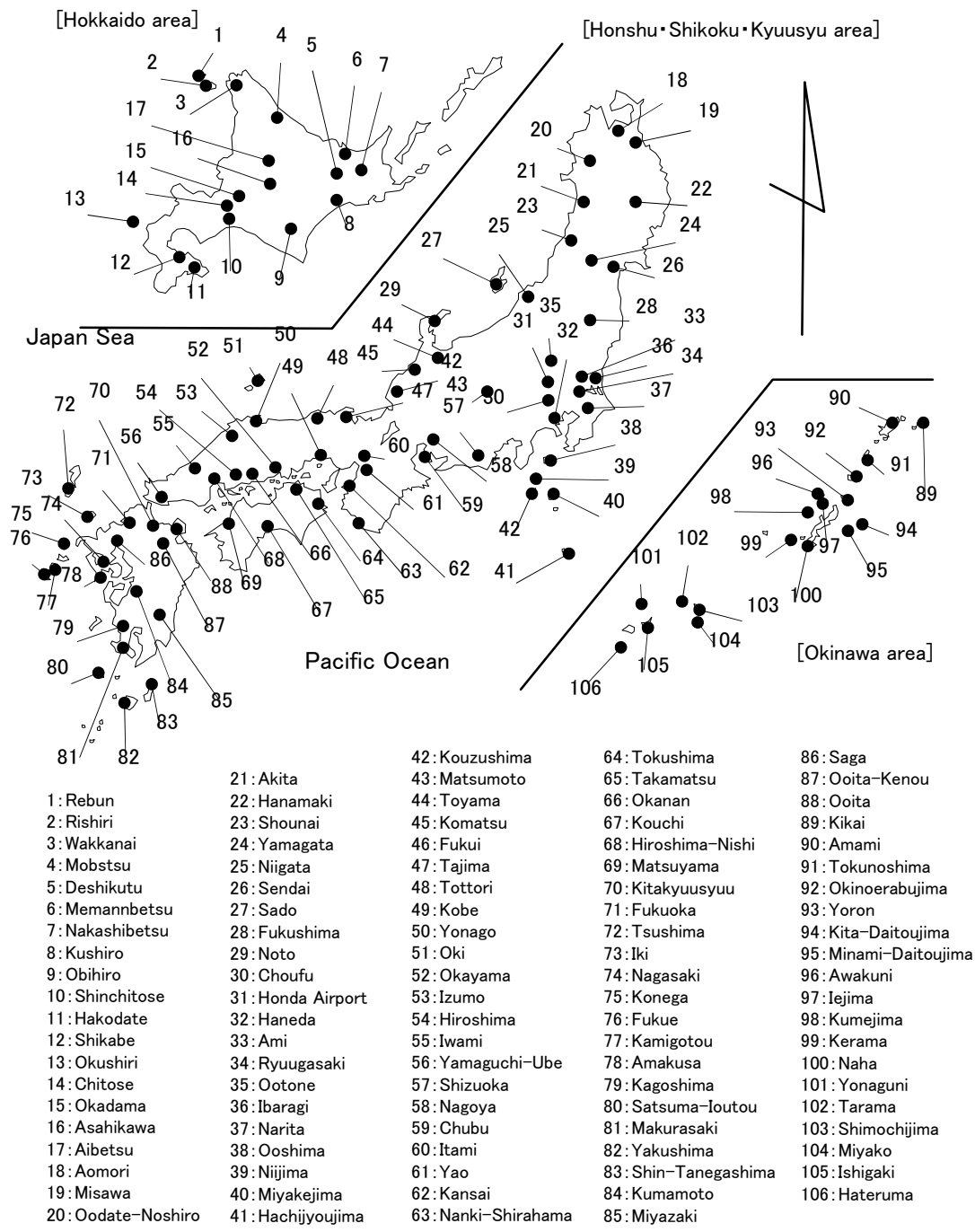

Figure 1: $\quad$ Locations of airports (in 2009). 


\section{Current bird strike situation}

International Birdstrike Committee (IBC) recommended the standards for Airdrome Bird/Wildlife Control in 2006 [2]. However, in present day, multiple bird strike incidents have occurred each day throughout the USA. In some cases, these bird strikes caused serious accidents. In 1960, an airplane took off at Boston Airport and each of the four engines ingested starlings [1]; as a result, the airplane crashed and 62 lives were lost. Recently, in 2009, an airplane made a forced landing on the Hudson River in New York due to a bird strike [3].

As of 2009, there were 106 airports in Japan, as shown in Figure 1; without exception, bird strikes have occurred at every airport. In Japan, despite efforts by the airports, an average of about 1,200 bird strikes have occurred annually from 2004-2008 [4]. Fortunately, in Japan, although serious accidents due to bird strike have not occurred, delays and suspensions of service have often occurred due to fuselage or engine damage from bird strikes.

\section{Investigation summary}

\subsection{Questionnaire}

A bird strike questionnaire was distributed to the officials of 70 airports at which there has been regular flight service. The content of the questionnaire is shown in Table 1. Also, the environmental conditions (precipitation; surrounding areas, e.g., residential areas, farmland, forests, seas, lakes, and cultivated fields; and the distance between the airport the nearest body of water) were determined, and the relationships between these factors and bird strike occurrence were analyzed. For the surrounding areas, a $3 \mathrm{~km}$ radius from the center of the airport was used, as shown in Figure 2. Also, regarding the distance between the airport and bodies of water, the shortest distance from airport to the coastline was measured, as shown in Figure 2.

Table 1: Questionnaire for airport officials.

Do you give us information of your airport on BS as below:

Q1. The number of cases of BS.

Q2. The number of times on the takeoff and landing for the last five years.

Q3. The number of users a year.

Q4-1. Measures against BS at the time of planning for the construction of airport.

Q4-2. Measures against BS in present day.

Q5.The time that BS occurs most frequently.

Q6. The quantity of annual precipitation around the airport.

Q7. The weather when BS occurs.(temperature, hourly precipitation, wind)

Q8. The actual damage due to BS in your airport.

Q9. Problems to manage the airport. 


\subsection{Risk analysis}

Tokyo's Haneda Airport was used as an example to analyze bird strike risk. $10 \%$ of the bird strikes in Japan have occurred at Haneda Airport [4]. Also, Haneda Airport recently opened a new runway, called "D runway", as shown in Figure 3. The bird strike risk is estimated to be high in the future, because the number of runways increases from three to four.
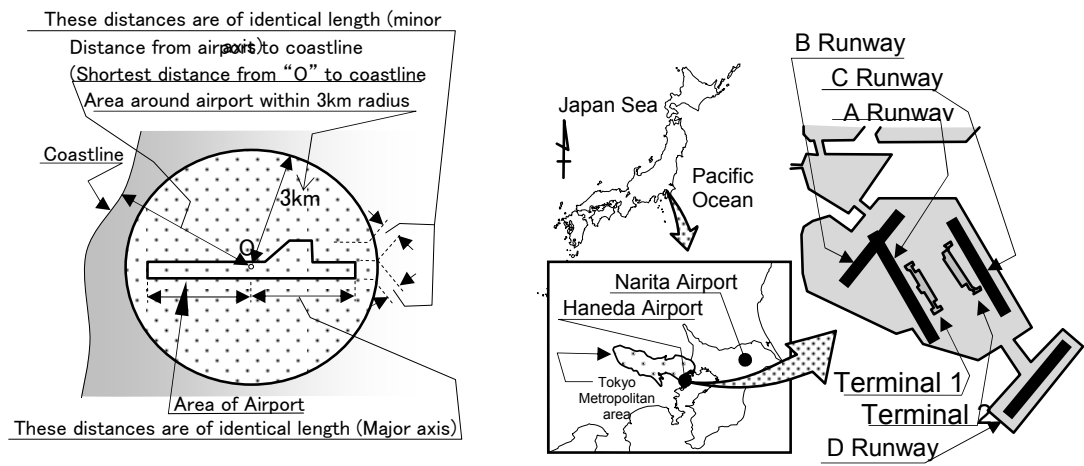

Figure 2: Measurement methods for bird strike factors.

Figure 3: $\quad$ Plane view of Haneda airport.

A bird strike risk simulation for Haneda Airport was performed in Crystal Ball (Standard Pack, Oracle corporation) using a Monte Carlo simulation. To determine the parameters of the risk simulation, an inspection of Haneda Airport was performed, and videos were taken of airplane takeoffs and landings. Also, experts from Tokyo Port Wild Bird Park near Haneda Airport were consulted to gain an understanding of bird behavior.

\section{Investigation results}

\subsection{Consideration of bird strike factors}

Forty responses from airport officials were obtained; 33 airports were selected for the analysis of bird strike factors. The remaining seven airports have gotten rid of birds, and very few bird strikes have been reported.

Tables 2 and 3 show the questionnaire responses and the relationships between some relevant factors (the number of takeoffs and landings, the times when bird strikes occurred, precipitation and temperature, and land use around the airport) and bird strike occurrence. These relationships are explained below:

\subsubsection{The number of bird strikes (Q1)}

As shown in Table 2, bird strikes have occurred throughout Japan. The airport with the highest bird strike incident rate is Kobe Airport at 52 per year, or about 
Table 2: $\quad$ Analysis of bird strike factors.

\begin{tabular}{|c|c|c|c|c|c|c|c|}
\hline No. & Name & $\begin{array}{c}\text { Annual } \\
\text { averaged } \\
\text { number of } \\
\text { bird strike } \\
\text { between } \\
2004 \text { and } \\
2009 \\
\end{array}$ & $\begin{array}{c}\text { Averaged } \\
\text { number of } \\
\text { takeoff and } \\
\text { landing } \\
\text { between } \\
2004 \text { and } \\
2009 \\
\end{array}$ & $\begin{array}{l}\text { Number of } \\
\text { passenger } \\
\text { in } 2009\end{array}$ & $\begin{array}{l}\text { Averaged } \\
\text { Amount of } \\
\text { rainfall } \\
\text { between } \\
2004 \text { and } \\
2009\end{array}$ & $\begin{array}{c}\text { Temperature in } \\
2009\end{array}$ & $\begin{array}{l}\text { Distance } \\
\text { from sea or } \\
\text { lake to } \\
\text { airport }\end{array}$ \\
\hline 4 & Monbetsu & 2.2 & 1028 & 47,977 & 442 & 6.8 & 0.86 \\
\hline 6 & Memanbetsu & 1.6 & 5699 & 893,618 & 477 & 6.4 & 4.26 \\
\hline 7 & Nakashibetsu & 2.2 & 3304 & 176,240 & 1005 & 6.0 & 17.0 \\
\hline 9 & Obihiro & 3.4 & 4719 & 609,938 & 779 & 7.2 & 31.2 \\
\hline 18 & Aomori & 9.0 & 9151 & $1,140,383$ & 1372 & 8.0 & 10.8 \\
\hline 20 & Oodate-Noshiro & 4.7 & 2081 & 125,160 & 1547 & 10.0 & 28.8 \\
\hline 21 & Akita & 27.8 & 7892 & $1,184,195$ & 1579 & 12.0 & 13.4 \\
\hline 22 & Hanamaki & 3.8 & 4251 & 361,185 & 2066 & 10.9 & 61.6 \\
\hline 23 & Shounai & 12.7 & 3778 & 392,995 & 1681 & 12.9 & 1.44 \\
\hline 24 & Yamagata & 2.6 & 5110 & 191,450 & 1192 & 12.1 & 55.2 \\
\hline 28 & Fukushima & 5.4 & 7484 & 426,869 & 1264 & 13.5 & 52.2 \\
\hline 29 & Noto & 2.8 & 2014 & 171,422 & 1962 & 13.3 & 6.21 \\
\hline 43 & Matsumoto & 4.0 & 4137 & 63,484 & 1028 & 12.2 & 80.8 \\
\hline 44 & Toyama & 23.6 & 5538 & $1,121,623$ & 2107 & 14.6 & 12.1 \\
\hline 48 & Tottori & 21.2 & 5228 & 306,516 & 1576 & 15.0 & 0.33 \\
\hline 49 & Kobe & 52.0 & 9869 & $2,579,674$ & 964 & 17.1 & 0.34 \\
\hline 51 & Oki & 3.2 & 1836 & 31,926 & 1487 & 14.5 & 1.19 \\
\hline 52 & Okayama & 23.6 & 6220 & $1,422,347$ & 1038 & 16.6 & 20.1 \\
\hline 53 & Izumo & 24.4 & 10696 & 755,656 & 1639 & 14.9 & 1.00 \\
\hline 55 & Iwami & 10.0 & 1874 & 69,472 & 1536 & 15.9 & 1.00 \\
\hline 56 & Yamaguchi-Ube & 14.8 & 3662 & 857,788 & 1470 & 16.1 & 0.32 \\
\hline 64 & Tokushima & 13.0 & 4260 & 145,545 & 1014 & 16.9 & 0.98 \\
\hline 76 & Fukue & 2.0 & 5017 & 147,689 & 2084 & 17.2 & 2.26 \\
\hline 79 & Kagoshima & 34.8 & 33,084 & $5,426,911$ & 2475 & 19.0 & 7.22 \\
\hline 86 & Saga & 42.4 & 4603 & 297,832 & 1549 & 16.9 & 0.60 \\
\hline 89 & Kikai & 4.75 & 3603 & 72,561 & 1797 & 21.9 & 0.30 \\
\hline 90 & Amami & 20.4 & 7160 & 555,008 & 2766 & 21.8 & 0.26 \\
\hline 91 & Tokunoshima & 6.5 & 1893 & 145,545 & 1788 & 21.9 & 0.10 \\
\hline 92 & Okinoerabujima & 4.0 & 6110 & 85,983 & 1708 & 22.6 & 1.98 \\
\hline 93 & Yoron & 6.25 & 1692 & 67,464 & 1758 & 22.9 & 0.99 \\
\hline 103 & Shimochijima & 16.8 & 14063 & 0 & 1817 & 23.9 & 0.63 \\
\hline 104 & Miyako & 24.6 & 7602 & $1,077,571$ & 1957 & 10.8 & 3.12 \\
\hline 105 & Ishigaki & 22.6 & 11925 & $1,845,317$ & 2061 & 24.6 & 0.65 \\
\hline \multicolumn{2}{|c|}{$\begin{array}{l}\text { Correlation coefficient } \\
\text { with number of BS }\end{array}$} & & 0.51 & 0.62 & 0.22 & 0.29 & -0.32 \\
\hline
\end{tabular}

one per week. However, the bird strike incident rate at Haneda Airport is higher than that of Kobe Airport [2]. 


\subsubsection{The number of takeoffs and landings and passengers (Q2 and Q3)}

As shown in Table 2, the bird strike incident rate increases as the number of takeoffs and landings and passengers increases. The correlation coefficients for the numbers of takeoffs and landings and passengers based on bird strike frequency are 0.51 and 0.62 , respectively; however, this is naturally to be expected.

\subsubsection{The times that bird strikes typically occur (Q5)}

Table 3 shows the time of day that bird strikes typically occurred for each airport. Note that half of the airports did not record the times at which bird strikes occurred. There is no apparent trend for the bird strike times among the various airports.

Table 3: $\quad$ Times of bird strike occurrences.

\begin{tabular}{|c|c|c|c|c|c|}
\hline No. & Name & Times when BS is apt to occur & No. & Name & Times when BS is apt to occur \\
\hline 4 & Monbetsu & Around noon & 56 & $\begin{array}{l}\text { Yamaguchi- } \\
\text { Ube }\end{array}$ & Between 17:00 and 20:00 \\
\hline 7 & Nakashibetsu & $\begin{array}{c}\text { Between half past } 12: 00 \text { and } \\
\text { half past } 13: 00\end{array}$ & 76 & Fukue & In the afternoon \\
\hline 21 & Akita & Between 9:00 and 13:00 & 86 & Saga & Around $14: 00$, around $18: 00$ \\
\hline 22 & Hanamaki & $\begin{array}{c}\text { Around } 10: 00 \text {, around half } \\
\text { past } 14: 30 \text {, and around } 16: 00\end{array}$ & 89 & Kikai & Between 11:00 and 12:00 \\
\hline 23 & Shounai & Between 8:00 and 9:00 & 90 & Amami & Between 7:00 and 10:00 \\
\hline 44 & Toyama & In the morning & 91 & Tokunoshima & Between 13:00 and 16:00 \\
\hline 48 & Tottori & After 16:00 & 103 & Shimochijima & Between 11:00 and 12:00 \\
\hline
\end{tabular}

\subsubsection{Precipitation and temperature (Q6 and Q7)}

As shown in Table 2, the bird strike frequency depends on the average precipitation and temperature. The precipitation in northeastern Japan is much less than in southwestern Japan, whereas the temperature in southeastern Japan is higher than in northeastern Japan. Therefore, bird strikes are more likely to occur at airports in southwestern Japan. In addition, regarding Q7, the answers from some respondents included the assessment that bird strikes were more likely to occur during rain events.

\subsubsection{Bird strike mitigation efforts and problems due to bird strike (Q4, Q8, and Q9)}

Some examples of actual bird strike issues from Q4, Q8, and Q9 are summarized as follows:

- Despite efforts to removal nesting places at the airport, nesting places appeared in other neighboring areas.

- The grass that is cut to inhibit nesting has been given to neighboring farmers who breed domestic animals. Therefore, the airport cannot use agricultural chemicals such as herbicides. As a result, the airport site has become a good habitat for birds.

- The specialists that exterminate birds with guns are aging. Therefore, their numbers are decreasing with each passing year.

-When the airports were constructed, the planners did not consider bird strike risk. 


\subsubsection{Land use around the airports}

Table 4 shows the classification of land use around the airports. The correlation coefficient for farms is -0.41 , meaning that as the farm area increases, the bird strike risk decreases. The correlation coefficient for a sea or lake is 0.27 , meaning that as the area of the nearby sea or lake increases, the bird strike risk increases. In addition, since the correlation coefficient for the distance between

Table 4: $\quad$ Details of land use around airports.

\begin{tabular}{|c|c|c|c|c|c|c|}
\hline \multirow{2}{*}{ No. } & \multirow{2}{*}{ Name } & Farm & Forest and field & Sea and Lake & town & \multirow{2}{*}{$\frac{\text { airport }}{(\mathrm{km})}$} \\
\hline & & \multicolumn{4}{|c|}{$(\%)$} & \\
\hline 4 & Monbetsu & 43.0 & 22.4 & 29.1 & 2.4 & 3.1 \\
\hline 6 & Memanbetsu & 93.0 & 0 & 0 & 1.7 & 5.3 \\
\hline 7 & Nakashibetsu & 90.2 & 0 & 0 & 5.9 & 3.9 \\
\hline 9 & Obihiro & 90.3 & 0 & 0 & 0 & 9.7 \\
\hline 18 & Aomori & 7.6 & 82.9 & 2.4 & 0 & 7.1 \\
\hline 20 & Oodate-Noshiro & 62.6 & 32.7 & 0 & 1.6 & 3.1 \\
\hline 21 & Akita & 2.9 & 91.3 & 0 & 0 & 5.7 \\
\hline 22 & Hanamaki & 77.8 & 0 & 0 & 14.9 & 7.3 \\
\hline 23 & Shounai & 78.2 & 0 & 17.3 & 0 & 4.5 \\
\hline 24 & Yamagata & 70.8 & 0 & 0 & 25.7 & 3.5 \\
\hline 28 & Fukushima & 54.6 & 39.3 & 0 & 2.4 & 3.8 \\
\hline 29 & Noto & 0 & 96.2 & 0 & 0 & 3.8 \\
\hline 43 & Matsumoto & 75.0 & 0 & 0 & 22.6 & 2.3 \\
\hline 44 & Toyama & 30.3 & 0 & 0 & 66.6 & 3.1 \\
\hline 48 & Tottori & 21.2 & 3.5 & 50.9 & 21.2 & 3.1 \\
\hline 49 & Kobe & 0 & 0 & 77.4 & 18.1 & 4.5 \\
\hline 51 & Oki & 0 & 32.0 & 59.6 & 4.8 & 3.6 \\
\hline 52 & Okayama & 0 & 92.7 & 0.8 & 0 & 6.5 \\
\hline 53 & Izumo & 32.6 & 24.4 & 34.0 & 6.7 & 2.3 \\
\hline 55 & Iwami & 27.6 & 39.2 & 26.6 & 6.6 & 3.0 \\
\hline 56 & Yamaguchi-Ube & 0 & 0 & 57.3 & 37.5 & 5.2 \\
\hline 64 & Tokushima & 40.8 & 0 & 42.9 & 9.5 & 6.8 \\
\hline 76 & Fukue & 75.6 & 20.8 & 1.4 & 0 & 2.2 \\
\hline 79 & Kagoshima & 36.4 & 58.1 & 0 & 0 & 5.5 \\
\hline 86 & Saga & 37.8 & 0 & 59.4 & 0 & 2.8 \\
\hline 89 & Kikai & 30.6 & 5.9 & 57.1 & 5.6 & 0.8 \\
\hline 90 & Amami & 27.7 & 12.8 & 53.2 & 2.1 & 4.2 \\
\hline 91 & Tokunoshima & 28.1 & 1.4 & 60.1 & 8.4 & 2.0 \\
\hline 92 & Okinoerabujima & 20.7 & 0 & 74.9 & 2.6 & 1.8 \\
\hline 93 & Yoron & 25.5 & 0 & 71.3 & 1.7 & 1.5 \\
\hline 103 & Shimochijima & 21.7 & 9.9 & 56.8 & 3.1 & 8.4 \\
\hline 104 & Miyako & 59.9 & 9.1 & 9.2 & 17.5 & 4.3 \\
\hline 105 & Ishigaki & 42.8 & 2.8 & 38.9 & 13.8 & 1.7 \\
\hline & $\begin{array}{l}\text { lation coefficient } \\
\text { number of BS }\end{array}$ & -0.41 & 0.07 & 0.27 & 0.16 & 0.07 \\
\hline
\end{tabular}


the airport and the coastline is -0.32 , it is clear that the existence of a sea or lake is a significant factor of bird strike risk.

\subsection{Risk analysis}

\subsubsection{Field investigation}

Based on observations from an area near the airport, the approach angles for the landing aircraft were approximately 2.5-4.5 degrees; takeoff angles were approximately 15-25 degrees. According to the experts from Tokyo Port Wild Bird Park, bird strikes typically occur at altitudes of $0-150 \mathrm{~m}$, which is the altitude range that birds fly near Haneda Airport.

\subsubsection{Risk analysis execution}

Probability distributions were assumed for an airplane and a bird passing through a section of runway. For the airplane, the probability distribution was assumed to be a normal distribution curve, as shown in Figure 4. For the bird, the probability distribution was assumed to be a maximum extreme value distribution curve, as shown in Figure 4. If the altitude of an airplane were equal to the altitude of a bird in the same section, it was assumed that a bird strike occurred. In addition, the risk analysis assumed that the diameter of the airplane was $5.0 \mathrm{~m}$.

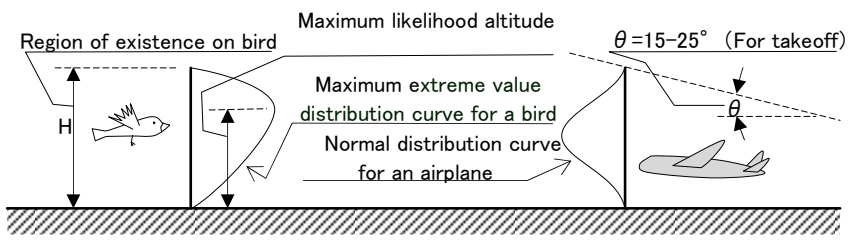

Figure 4: $\quad$ Probability curves for airplanes and birds.

For the airplane, the parameters that determined the normal distribution curve profile were the minimum altitude, maximum altitude, average altitude, and standard deviation of altitude; those values were assumed as listed in Table 5.

Table 5: $\quad$ Assumed parameters for the maximum extreme value distribution.

\begin{tabular}{|c|c|c|c|c|}
\hline \multirow{2}{*}{ For Landing } & \multicolumn{4}{|c|}{ Angle (in degree) $\quad$ (Field observation=3.95) } \\
\hline & Minimum & Average & Maximum & \\
\hline Angel of airplane's locus to ground & 2.50 & 3.5 & 4.50 & \\
\hline Section & \multicolumn{3}{|c|}{ Altitude(m) } & Standard Deviation $(\mathrm{m})$ \\
\hline Horizontal distance from landing point $=0 \mathrm{~m}$ & 0 & 2.50 & 5.00 & 4.0 \\
\hline Horizontal distance from landing point $=500 \mathrm{~m}$ & 21.8 & 34.5 & 39.4 & 5.0 \\
\hline Horizontal distance from landing point $=1000 \mathrm{~m}$ & 43.7 & 69.0 & 78.7 & 6.0 \\
\hline Horizontal distance from landing point $=1500 \mathrm{~m}$ & 65.5 & 104 & 118 & 7.0 \\
\hline Horizontal distance from landing point $=2000 \mathrm{~m}$ & 87.3 & 138 & 157 & 8.0 \\
\hline \multirow{2}{*}{ For Takeoff } & \multicolumn{4}{|c|}{ Angle (in degree) (Field observation=18.6) } \\
\hline & Minimum & Average & Maximum & \\
\hline Angel of airplane's locus to ground & 15.0 & 20.0 & 25.0 & \\
\hline Section & \multicolumn{3}{|c|}{ Altitude(m) } & Standard Deviation $(\mathrm{m})$ \\
\hline Horizontal distance from landing point $=0 \mathrm{~m}$ & 0 & 2.50 & 5.00 & 4.0 \\
\hline Horizontal distance from landing point $=150 \mathrm{~m}$ & 40.2 & 50.6 & 69.9 & 5.0 \\
\hline Horizontal distance from landing point $=300 \mathrm{~m}$ & 80.4 & 101 & 140 & 6.0 \\
\hline Horizontal distance from landing point $=450 \mathrm{~m}$ & 121 & 152 & 210 & 7.0 \\
\hline
\end{tabular}


For the bird, the parameters that determined the maximum extreme distribution curve profile were the altitude range and maximum probable altitude. Twentyfive cases were chosen based on the experts' suggestion that small birds fly at altitudes less than about $80 \mathrm{~m}$. Therefore, in this study, we conducted the simulation under the condition for small birds; details of the 25 cases are shown in Table 6.

Table 6: Assumed parameters for the maximum extreme value distribution.

\begin{tabular}{|c|c|c|c|c|c|}
\hline \multirow{2}{*}{ Region of existence on bird } & \multicolumn{5}{|c|}{ Maximum likelihood altitude (m) } \\
\cline { 2 - 6 } & $\mathrm{H} / 4$ & $\mathrm{H} / 3$ & $\mathrm{H} / 2$ & $2 \mathrm{H} / 3$ & $3 \mathrm{H} / 4$ \\
\hline Altitude $=0$ to $40 \mathrm{~m}$ & 10.0 & 13.3 & 20.0 & 26.7 & 30.0 \\
\hline Altitude $=0$ to $50 \mathrm{~m}$ & 12.5 & 16.7 & 25.0 & 33.0 & 37.5 \\
\hline Altitude $=0$ to $60 \mathrm{~m}$ & 15.0 & 20.0 & 30.0 & 40.0 & 45.0 \\
\hline Altitude $=0$ to $70 \mathrm{~m}$ & 17.5 & 23.3 & 35.0 & 46.7 & 52.5 \\
\hline Altitude $=0$ to $80 \mathrm{~m}$ & 20.0 & 26.7 & 40.0 & 53.3 & 60.0 \\
\hline
\end{tabular}

Although there were about 371,000 takeoffs and landings in 2010, that number is expected to increase to about 447,000 in the near future. Therefore, for the Monte Carlo simulation, the number of takeoffs and landings was assumed to be 55,857 per runway ( $=447.000$ times/4 runways).

Table 7: $\quad$ Risk of bird strike during takeoff.

\begin{tabular}{|c|c|c|c|c|c|}
\hline \multirow{2}{*}{$\begin{array}{l}\text { Range } \\
\text { of } \\
\text { altitude } \\
\text { on bird } \\
(\mathrm{m})\end{array}$} & \multirow{2}{*}{$\begin{array}{l}\text { Maximum } \\
\text { 1likelihood } \\
\text { value } \\
\text { (m) }\end{array}$} & \multicolumn{4}{|c|}{ Risk of BS occurrence for takeoff (\%) } \\
\hline & & $\begin{array}{l}\text { Averaged altitude } \\
\text { of airplane }=0 \mathrm{~m}, \\
\text { Horizontal distance } \\
\text { after takeoff }=0 \mathrm{~m}\end{array}$ & $\begin{array}{c}\text { Averaged altitude } \\
\text { of airplane }=50.6 \mathrm{~m} \text {, } \\
\text { Horizontal distance } \\
\text { after takeoff }=150 \mathrm{~m}\end{array}$ & $\begin{array}{c}\text { Averaged altitude } \\
\text { of airplane }=101.1 \mathrm{~m}, \\
\text { Horizontal distance } \\
\text { after takeoff }=300 \mathrm{~m}\end{array}$ & $\begin{array}{l}\text { Averaged altitude } \\
\text { of airplane }=151.7 \mathrm{~m} \text {, } \\
\text { Horizontal distance } \\
\text { after takeoff }=450 \mathrm{~m}\end{array}$ \\
\hline \multirow{5}{*}{$\begin{array}{c}0 \\
- \\
40\end{array}$} & 10.0 & 7 & 0 & 0 & 0 \\
\hline & 13.3 & 6 & 0 & 0 & 0 \\
\hline & 20.0 & 4 & 0 & 0 & 0 \\
\hline & 26.7 & 2 & 0 & 0 & 0 \\
\hline & 30.0 & 2 & 0 & 0 & 0 \\
\hline \multirow{5}{*}{$\begin{array}{c}0 \\
- \\
50\end{array}$} & 12.5 & 5 & 2 & 0 & 0 \\
\hline & 16.7 & 7 & 2 & 0 & 0 \\
\hline & 25.0 & 2 & 4 & 0 & 0 \\
\hline & 33.0 & 1 & 5 & 0 & 0 \\
\hline & 37.5 & 0 & 6 & 0 & 0 \\
\hline \multirow{5}{*}{$\begin{array}{c}0 \\
- \\
60\end{array}$} & 15.0 & 4 & 4 & 0 & 0 \\
\hline & 20.0 & 3 & 5 & 0 & 0 \\
\hline & 30.0 & 1 & 8 & 0 & 0 \\
\hline & 40.0 & 0 & 11 & 0 & 0 \\
\hline & 45.0 & 0 & 14 & 0 & 0 \\
\hline \multirow{5}{*}{$\begin{array}{c}0 \\
- \\
70\end{array}$} & 17.5 & 4 & 5 & 0 & 0 \\
\hline & 23.3 & 2 & 6 & 0 & 0 \\
\hline & 35.0 & 0 & 9 & 0 & 0 \\
\hline & 46.7 & 0 & 12 & 0 & 0 \\
\hline & 52.5 & 0 & 12 & 0 & 0 \\
\hline \multirow{5}{*}{$\begin{array}{c}0 \\
- \\
80\end{array}$} & 20.0 & 3 & 3 & 0 & 0 \\
\hline & 26.7 & 1 & 6 & 0 & 0 \\
\hline & 40.0 & 0 & 9 & 0 & 0 \\
\hline & 53.3 & 0 & 12 & 0 & 0 \\
\hline & 60.0 & 0 & 11 & 0 & 0 \\
\hline
\end{tabular}




\subsection{Simulation results}

From the simulation results provided in Tables 7 and 8, a high bird strike risk can be seen. Note that the bird was assumed to exist in the runway section in every calculation and the simulation did not consider three-dimensional effects. However, Tables 7 and 8 can be considered qualitative expressions of bird strike risk.

Table 8: $\quad$ Risk of bird strike during landing.

\begin{tabular}{|c|c|c|c|c|c|c|}
\hline \multirow[b]{2}{*}{$\begin{array}{l}\text { Range } \\
\text { of } \\
\text { altitude } \\
\text { on bird } \\
(\mathrm{m})\end{array}$} & \multirow[b]{2}{*}{$\begin{array}{l}\text { Maximum } \\
\text { llikelihood } \\
\text { Value (m) }\end{array}$} & \multicolumn{5}{|c|}{ Risk of BS occurrence for landing (\%) } \\
\hline & & $\begin{array}{c}\text { Averaged } \\
\text { altitude of } \\
\text { airplane }=0 \mathrm{~m} \text {, } \\
\text { Horizontal } \\
\text { distance before } \\
\text { landing }=0 \mathrm{~m}\end{array}$ & $\begin{array}{c}\text { Averaged } \\
\text { altitude of } \\
\text { airplane }=34.5 \mathrm{~m} \text {, } \\
\text { Horizontal } \\
\text { distance before } \\
\text { landing }=500 \mathrm{~m}\end{array}$ & $\begin{array}{c}\text { Averaged } \\
\text { altitude of } \\
\text { airplane }=69.0 \mathrm{~m} \text {, } \\
\text { Horizontal } \\
\text { distance before } \\
\text { landing }=1000 \mathrm{~m}\end{array}$ & $\begin{array}{c}\text { Averaged altitude } \\
\text { of } \\
\text { airplane }=103.6 \mathrm{~m} \text {, } \\
\text { Horizontal } \\
\text { distance before } \\
\text { landing }=1500 \mathrm{~m}\end{array}$ & $\begin{array}{c}\text { Averaged } \\
\text { altitude of } \\
\text { airplane }=138.1 \\
\mathrm{~m}, \\
\text { Horizontal } \\
\text { distance before } \\
\text { landing }=2000 \\
\mathrm{~m}\end{array}$ \\
\hline \multirow{5}{*}{$\begin{array}{c}0 \\
- \\
40\end{array}$} & 10.0 & 7 & 9 & 0 & 0 & 0 \\
\hline & 13.3 & 6 & 10 & 0 & 0 & 0 \\
\hline & 20.0 & 4 & 12 & 0 & 0 & 0 \\
\hline & 26.7 & 2 & 15 & 0 & 0 & 0 \\
\hline & 30.0 & 2 & 16 & 0 & 0 & 0 \\
\hline \multirow{5}{*}{$\begin{array}{c}0 \\
- \\
50\end{array}$} & 12.5 & 6 & 9 & 0 & 0 & 0 \\
\hline & 16.7 & 4 & 10 & 0 & 0 & 0 \\
\hline & 25.0 & 2 & 12 & 0 & 0 & 0 \\
\hline & 33.0 & 1 & 14 & 0 & 0 & 0 \\
\hline & 37.5 & 0 & 15 & 0 & 0 & 0 \\
\hline \multirow{5}{*}{$\begin{array}{c}0 \\
- \\
60\end{array}$} & 15.0 & 4 & 9 & 0 & 0 & 0 \\
\hline & 20.0 & 3 & 10 & 0 & 0 & 0 \\
\hline & 30.0 & 1 & 12 & 0 & 0 & 0 \\
\hline & 40.0 & 0 & 14 & 1 & 0 & 0 \\
\hline & 45.0 & 0 & 15 & 1 & 0 & 0 \\
\hline \multirow{5}{*}{$\begin{array}{c}0 \\
- \\
70\end{array}$} & 17.5 & 4 & 8 & 1 & 0 & 0 \\
\hline & 23.3 & 2 & 9 & 2 & 0 & 0 \\
\hline & 35.0 & 0 & 10 & 3 & 0 & 0 \\
\hline & 46.7 & 0 & 9 & 5 & 0 & 0 \\
\hline & 52.5 & 0 & 7 & 7 & 0 & 0 \\
\hline \multirow{5}{*}{$\begin{array}{c}0 \\
- \\
80\end{array}$} & 20.0 & 3 & 9 & 2 & 0 & 0 \\
\hline & 26.7 & 1 & 9 & 3 & 0 & 0 \\
\hline & 40.0 & 0 & 10 & 5 & 0 & 0 \\
\hline & 53.3 & 0 & 6 & 10 & 0 & 0 \\
\hline & 60.0 & 0 & 3 & 12 & 0 & 0 \\
\hline
\end{tabular}

\subsubsection{Takeoff case}

As shown in Table 7, a high bird strike risk exists after takeoff when the airplane travels $150 \mathrm{~m}$ in the horizontal direction and is at an altitude of 30 to $60 \mathrm{~m}$. 


\subsubsection{Landing case}

As shown in Table 8, a high bird strike risk exists on approach when the airplane is $500 \mathrm{~m}$ in the horizontal direction from touchdown and at an altitude of 20 to $40 \mathrm{~m}$. Also, in comparing takeoffs and landings, the bird strike risk is higher during landing than during takeoff because the airplane remains in the bird altitude range for a longer period of time during landing (due to the shallow approach angle).

\subsection{Bird strike countermeasures}

It is clear that bird strikes tend to occur immediately after takeoff and before landing. Therefore, for takeoff, acoustic bird deterrents should be installed along the runway at adequate intervals. For landing, radar systems should be able to detect birds near the airport; if the birds can be detected by radar, bird strikes should be preventable by the air traffic control system.

\section{Conclusions}

Precautions were proposed for planners to consider when opening a new airport. Using questionnaires, officials from airports around Japan provided data on airport conditions, usage, and bird strike history. From this data, it is clear that bird strike occurrence depends highly on the proximity and size of a sea or lake. Therefore, airport planners should consider bird strike risk if the airport will be constructed near a sea or lake.

A risk analysis was conducted using a Monte Carlo simulation of Tokyo's Haneda Airport as an example. Probability distributions were assumed for an airplane and a bird passing through a section of runway. The bird strike risk was shown to be higher for landings than for takeoffs. Furthermore, for landings, the bird strike risk tends to be high when the airplane is within $500 \mathrm{~m}$ (in the horizontal direction) of touchdown. Bird strike countermeasures were suggested for both takeoff and landing: For takeoff, acoustic bird deterrents should be installed along the runway at adequate intervals; for landing, radar should detect birds around the runway, and bird strikes should be prevented by the air traffic control system.

\section{References}

[1] Federal Aviation Administration, FAA Wildlife Strike Database, http://wildlife-mitigation.tc.faa.gov/

[2] International Birdstrike Comittee, Recommended Practices No.1,Standards for aerodrome Bird/Wildlife Control(Issue 1), http://www.birdstrike.org/

[3] BBC NEWS, Bird strike confirmed in US crash, http://news.bbc.co.uk/

[4] Cabinet Office, Government of Japan, Grappling on prevention of Bird Strike (in Japanese), http://www8.cao.go.jp/ 